\title{
A Biharugrai halastórendszer ökoszisztéma szolgáltatásai a helyiek szemszögéböl-többszempontú szocio-kulturális értékelés
}

\author{
Palásti Péter és Kerepeczki Éva \\ Nemzeti Agrárkutatási és Innovációs Központ, Halászati Kutatóintézet \\ 5540 Szarvas, Anna-liget 8. \\ e-mail:palasti.peter@haki.naik.hu
}

\begin{abstract}
Összefoglaló: A nagy folyószabályozások mellékhatásaként természetes vizes élőhelyeink kiterjedése, illetve az általuk nyújtott ökoszisztéma szolgáltatások mennyisége és minősége radikálisan lecsökkent. Szerepüket a Biharugrai-halastavakhoz hasonló természetközeli élőhelyek részben pótolhatják, ami miatt hosszútávú hasznosításuk fontos kérdés. Célunk, hogy támogassuk halastavaink fenntartható használatát, azok szolgáltatásainak összegyűjjtésével és szocio-kulturális értékelésével valamint, hogy új módszereket alakítsunk ki a szolgáltatások rangsorba állítására. Vizsgálataink során 10 helyi kulcsinformátorral végeztünk strukturált interjúkat a Biharugrai tavak szolgáltatásainak összegyüjtésére majd az így kapott lista alapján szocio-kulturális felmérést készítettünk 3 közeli településen azok fontossági sorrendjének megállapítására egy hazai viszonylatban új, általunk kialakított módszer felhasználásával. Eredményeink között 14 feltárt szolgáltatás szerepel, melyek közül a helyiek a haltermelést, a rekreációt és a faji sokszínűséget sorolták az első három helyre. További, elsősorban a demográfiai tényezők hatásával, a vizsgálandó települések kiválasztásával és az általunk használt módszer előnyeivel kapcsolatos eredményeinkkel korábbi, hazai vizsgálatok megállapításait és eljárásait egészítettük ki.
\end{abstract}

Kulcsszavak: ökoszisztéma szolgáltatások, szocio-kulturális értékelés, Biharugrai-halastavak

\section{Bevezetés}

Magyarországon a 19. század környékén erőteljes igény lépett fel az ország főbb folyóinak szabályozására a gyakori árvizek elleni hatékonyabb védekezés, az új termő- és lakóterületek felszabadítása, illetve a hajózási útvonalak korszerüsítése érdekében (Horoszné 2010, Ungvári 2012). Ebben a szellemiségben kezdődött meg 1846-ban a kor legjelentősebb tájátalakító projektje, a Vásárhelyi Pál-terv (Deák 1996), amely során a Tisza hazai szakaszán végzett kanyarulat átvágásokkal a folyó hosszát végül 1419 km-ről 962 km-re csökkentették (Bezdán 2011, Vágás 1996). 
A nagymértékủ átalakítások azonban számos nem várt következménnyel jártak, melyek közül kiemelkedik a természetes vizes élöhelyek (pl. mocsarak, lápok) kiterjedésének radikális csökkenése, valamint fennmaradó területeik minőségének leromlása (Somogyi 2000, Ungvári 2012). Utóbbi oka a folyók töltések közé szorítása, amivel megváltoztatták azok vízutánpótló képességét (tehát az időszakos elöntéseket) és ezáltal azokat a szabályozó funkciókat, melyek a folyók melletti vizes élőhelyeket „stabilan” és változatosan tartották (Csatári et al. 2001, Rakonczai 2001, Völgyesi 2005, 2009). Ez a stabilitás és a változatosság az ún. „természeti töke” két legalapvetőbb forrása (de Groot 2006). Ha lecsökken egy adott terület természeti tőkéje, akkor az megváltoztathatja az általa nyújtott ökoszisztéma szolgáltatások körét és minőségét, sőt egy bizonyos szint után maga az élőhely is tartósan átalakul egy új egyensúlyi állapot felvételével (Kovács et al. 2011, Ungvári 2012). Az ilyen degradálódott élőhelyek rehabilitációja költséges és hosszú folyamat (Margóczi 1998), eközben pedig végig megmarad az igény az általuk nyújtott szolgáltatások iránt. Szerencsére nemcsak a természetes élőhelyek tudnak szolgáltatásokat nyújtani: a Millennium Ecosystem Assessment (MEA 2005) megfogalmazása szerint az ember által kialakított élőhelyek is képesek rá, sőt Wu és munkatársainak álláspontja szerint (Wu et al. 2008) a természetes és a mesterséges területek ökoszisztéma szolgáltatásai nagyon is hasonlítanak egymásra. Ebből kiindulva úgy gondoljuk, hogy extenzív és fél-intenzív módon kezelt, természetközeli élővilággal rendelkező halastavaink segítségével bizonyos mértékben helyettesíthetjük, pótolhatjuk sérült természetes vizes élőhelyeink javait (például a vonuló madárállományok számára nyújtott fészkelőhelyeket), legalábbis a helyreállítások idejére.

Kutatásunk célja, hogy hozzájáruljunk hazánk természetközeli halastavainak fenntarthatóbb használatához és fejlesztéséhez az általuk nyújtott ökoszisztéma szolgáltatások összegyüjtésével és azok több, különböző szempontból történő elemzésével (Martín-López et al. 2014), mellyel információforrást nyújthatunk a döntéshozás számára a jövőbeli fenntartási tervek készítéséhez (Kelemen et al. 2010).

\section{Irodalmi áttekintés}

\section{A Biharugrai-halastavak}

A Biharugrai-halastavak együttesen Magyarország második legnagyobb, körtöltéses, természetközeli halastórendszerét alkotják (Bíró 2009, Oláh et al. 2009), amely a magyar-román határ közelében helyezkedik el, Békés megye északkeleti 
sarkában. Két fő egysége a 28 mederből álló Ugrai-egység (748 ha), illetve a Begécsi-egység, a maga 24 medrével (1172 ha).

Kiépítését 1910-ben kezdték meg, majd szakaszosan újabb és újabb tavakkal egészítették ki, míg végül 1967-re elérte mai méreteit: az első halastavakat (Bodor, Cigány, Csík, Ludas, Szilas) 1913-ra alakították ki, majd a munkálatokat tovább folytatták 1939 és 1944 (Zöldhalmi, Emlék), valamint 1951 és 1959 között (Gazdák). A Begécsi-egység kialakítását szintén az utóbbi időszakban kezdték meg (Nagy-Sziki, Új-tó), amelyet 1962 és 1967 között tovább bővítettek az ún. „Számozott (1-9.)” tavakkal. A vízutánpótlást elsődlegesen a Sebes-Körösböl, átemelő szivattyúk segítségével oldják meg, ahonnan a vizet egy 4 km hosszú tápláló betoncsatornán, illetve az azt követő ásott csatornarendszeren keresztül juttatják el a tavakhoz. A lecsapoláskor elvezetett vizet a Holt-Sebes-Körösbe, valamint a Toprongyos-Korhány-csatornába engedik (Tőgye 2006, Tóth 2017).

Ez a halastórendszer jelentős természetvédelmi értékkel bír: a tavak és azok környéke a Kis-Sárrét kistáj részét képezik, ahol a folyószabályozások előtt még elsősorban szikes rétekkel, hátakkal illetve nem szikes mocsarakkal lehetett találkozni, melyeket föleg legeltetésre alkalmaztak (Stefanovits et al. 1999). Utóbbi maradványai (pl. Ugrai-rét) több helyen még ma is megtalálhatóak (Juhász et al. 2000, Penksza et al. 2010). A terület vegetációját megközelítőleg 300 magasabb rendü, köztük 40 védett és 3 fokozottan védett növényfaj alkotja (Duray 2009), faunája pedig kiemelkedően gazdag, elsősorban az itt megfigyelhető, közép-európai szinten is meghatározó, áttelelő és vonuló madárállománynak köszönhetően (Tóth et al. 2017, Tőgye 2006).

A kistáj értékeit szerencsére viszonylag korán felfedezték, ennek köszönhetően a halastavakat, valamint a hozzájuk tartozó mocsaras területeket és szikes pusztákat már 1949-ben helyi védelem alá helyezték. Ezután, 1956-ban, a halastavak a Magyar Madártani Egyesülethez kerültek és egy részbeni védettséget kaptak. 1989-ben Fontos Madárélőhellyé (IBA HU30) nyilvánították. Országos védelmet először 1990-ben kapott, amikor a 6/1990. (III. 31.) KVM rendelettel megalakult a 7991 hektár kiterjedésü Biharugra Tájvédelmi Körzet, majd 1997-ben a 3/1997. (I. 8.) KTM rendelettel a Körös-Maros Nemzeti Park része lett (Oláh et al. 2009). Ugyanebben az évben felkerült a Ramsari területek listájára is. Területén - amelyből 1424 hektár fokozottan védett (Tóth et al. 2017) - már 1993. augusztus 15. óta tiltott a vízivadak vadászata (IUCN 1995).

\section{Ökoszisztéma szolgáltatások és azok értékelése}

Az ökoszisztéma szolgáltatások mindazok a kézzel fogható és nem fogható javak/ szolgáltatások, melyekkel a különbözö ökológiai rendszerek hozzájárulnak az 
emberi társadalom fennmaradásához és jóllétének (well-being) megteremtéséhez (Kelemen 2013).

Napjainkban ezek a szolgáltatások igen nagy szerepet töltenek be a nemzetközi természetvédelmi politikában (Kovács et al. 2011), melynek köszönhetően ma már nagy mennyiségben állnak rendelkezésre olyan hazai, de elsősorban külföldi tanulmányok, melyek különböző módszerek segítségével próbálják meg összegyüjteni, majd valamilyen szempont szerint értékelni természetes (Daily 1997, Martín-López et al. 2014, Palomo et al. 2011) illetve mesterséges élőhelyek (Mathé \& Rey-Valette 2015, Reilly et al. 2018, Wu et al. 2008), szolgáltatásait. Ezek közül manapság egyre nagyobb hangsúly helyeződik azon tanulmányokra, melyek a helyi érdekeltek és különböző rétegek bevonása mellett, ún. szocio-kulturális értékelés kivitelezésével próbálják feltárni egy-egy adott terület szolgáltatásainak rangsorát a rájuk irányuló igények és megítélések alapján (Andersson et al. 2015, Chan et al. 2012, Kelemen et al. 2015, Martín-López et al. 2014, Palomo et al. 2011). Számos negatív példán keresztül (pl. West 2006) kellett megtanulnunk, hogy az élőhelyek és a természeti értékek fenntartható kezelése illetve az azt szükségessé tevő okok és szándékok teljes körü megértése nem valósítható meg teljes körüen a helyi közösségek véleményeinek bevonása nélkül (Balmford 2002, Pretty 2003). Utóbbiak vizsgálatához több különböző szocio-kulturális módszer (pl. narratív és deliberatív módszerek, jövőkép tervezés stb.) áll rendelkezésre melyek mindegyike más és más erősséggel és gyengeséggel bír. Közülük az egyik legelterjedtebb eljárás az általunk is alkalmazott ún. „preferencia alapú” módszer, ami a szolgáltatások szociális sorrendjét az emberek hozzájuk rendelt tudása, megítélése és értékei alapján adja meg (Santos-Martin et al. 2017). Valamennyi módszer kivitelezéséhez társadalom-tudományi technikákra, pl. interjúkra és kérdőívekre van szükség, melyek megfelelő végrehajtásához ma már számos összefoglaló és útmutató áll rendelkezésre (Babbie 2002, Newing et al. 2011).

Mindezek ellenére sajnos nagyon kevés olyan kutatással lehet találkozni, melyek a vizes élőhelyeken belül a gazdálkodásba vont természetközeli halastavak ökoszisztéma szolgáltatásaival foglalkoznának (pl. Blayac 2014, Mathé \& Rey-Valette 2015). Az egyetlen jelentősebb hazai kivételt Tóth és munkatársainak, 2017-ben elvégzett kutatása jelenti (Tóth et al. 2017), amelyben hozzánk hasonlóan a Biharugrai halastórendszer szolgáltatásainak összegyüjtését és szocio-kulturális értékelését tüzték ki célul. Munkájuk során dokumentumelemzés segítségével gyüjtötték össze a Biharugrai-halastavak szolgáltatásait, majo 5 közeli település (Biharugra, Zsadány, Geszt, Mezögyán, Körösnagyharsány) lakosságának körében végeztek fotótablóval kiegészített kérdőívezést, melyhez a szükséges mintaelemszámot az egyes települések lakosságának méretével ará- 
nyosan határozták meg az ún. „kvóta alapú mintavétel” (Lehota 2001, Newing et al. 2011) segítségével. A kérdöívekben többek között arra kérték az alanyokat, hogy értékeljék a feltárt szolgáltatásokat egy 1-5-ig terjedő skálán, amely alapján kialakították a szolgáltatások sorrendjét. Eredményeik alapján a helyi lakosság számára a természetes élőhelyek (1.), a környezeti nevelés (2.), a haltermelés (3.), a rekreáció (4.) és az esztétika/tájképi jelentőség (5.) minősült az öt legfontosabb szolgáltatásnak.

Kutatásunk során arra törekedtünk, hogy tovább fejlesszük a természetközeli halastavak vizsgálatára felhasználható módszerek körét, illetve újabb információkkal és javaslatokkal egészítsük ki a kevés korábbi vizsgálat (Tóth el al. 2017) eredményeit annak érdekében, hogy a lehető legpontosabb képet nyújthassuk a Biharugrai-halastavak ökoszisztéma szolgáltatásairól és azok megítéléséről.

\section{Módszerek}

\section{Szolgáltatásgyüjtés}

A Biharugrai-halastavak által nyújtott ökoszisztéma szolgáltatások összegyüjtésére feltáró jellegü, strukturált interjúkat készítettünk tíz, ún. „kulcsinformátor” bevonásával (Kelemen 2013, Newing et al. 2011), akik jelen esetben olyan személyek voltak, akik foglalkozásukból adódóan jól ismerték a tavakat és annak értékeit (pl. természetvédelmi őrkerület-vezetők, halgazdaságok koordinátorai, halászok stb.). Jelentős részüket elözetesen választottuk ki, arra törekedve, hogy segítségükkel minél több érdekelt csoport szempontjából alkothassunk képet a tavakról és azok szolgáltatásainak formáiról. A többi interjúalanyt a már meglévők javaslatai alapján kerestük fel az ún. „hólabda módszer” segítségével (Babbie 2002, Newing et al. 2011).

A közel 1 órás interjúkat minden esetben egy rövid tájékoztatóval kezdtük, melyben tömören felvázoltuk a kutatás lényegét és az ökoszisztéma szolgáltatásokkal kapcsolatos általános tudnivalókat (fogalom, fö kategóriák). A bevezetést követően bemutattunk az interjúalanyok számára egy elözetes, általános listát, amely tartalmazta hazánk természetközeli halastavainak potenciális ökoszisztéma szolgáltatásait (Kerepeczki et al. 2011), majd arra kértük a kulcsinformátorokat, hogy válogassák ki a felsoroltak közül azokat, melyekkel a Biharugrai-halastavak is rendelkeznek (Palomo et al. 2011). A szolgáltatások végleges listájára csupán azokat a javakat írtuk fel, melyeket a tíz kulcsinformátorból legalább egy alátámasztott. Mivel kutatásunk egyik legalapvetőbb feladata természetes vizes élőhelyeink helyettesítési lehetőségeinek vizsgálata, ezért a kulcsinformátorok által feltárt javakat a "The Economics of Ecosystem and Biodiversity (TEEB)” 
keretrendszere alapján csoportosítottuk (ellátó-, kulturális-, élőhelyi- és szabályzó szolgáltatások), ugyanis az külön kategóriát szentel az élőhelyi szolgáltatások számára (Kovács et al. 2011, TEEB 2010).

Az interjúk további részében arról kérdeztük az alanyokat, hogy tapasztaltak-e valamilyen összefüggést, pozítív vagy negatív irányú kapcsolatot, ún. „szinergiákat” és „trade-off” jelenségeket (TEEB 2010, Turkelboom 2016, Ungvári et al. 2012) az általuk feltárt egyes szolgáltatások között. Utóbbival azokat az elsődleges szolgáltatásokat próbáltuk kimutatni, melyek változása jelentős hatást gyakorolna a többi szolgáltatásra nézve, és ezért megőrzésük kiemelt fontosságot élvez. Az önkéntes interjúalanyok személyiségi jogainak tiszteletben tartása és az információ szabadabb áramlása érdekében minden résztvevőnek névtelenséget biztosítottunk és valamennyiükkel négyszemközt beszéltünk. Az interjúk szövegéről minden esetben jegyzeteket készítettünk, illetve az alanyok elözetes engedélye mellett hangrögzítő segítségével fel is vettük azokat az egyes interjúkról szóló összefoglalók és a fontosabb információk szó szerint való idézése érdekében.

\section{A szolgáltatások szocio-kulturális értékelése}

A preferencia alapú szocio-kulturális értékelés célja az ökoszisztéma szolgáltatások iránti társadalmi igény feltárása azáltal, hogy az érintett közösségek (jelen esetben a Biharugrai-halastavak környékén élő személyek) kinyilvánított ismeretei és igényei alapján sorrendbe állítja a kérdéses szolgáltatásokat és ahhoz figyelembe veszi az emberek választásait befolyásoló különböző társadalmi tényezőket is (Kelemen \& Pataki 2014, Martin-López et al. 2014, Santos-Martin et al. 2017).

Az értékelés elvégzéséhez a kulcsinformátorokkal végzett strukturált interjúkból származó eredményeink alapján létrehoztunk egy preferencia-kérdőívet (Chan et al. 2012), amely kivitelezéséhez egy általunk kialakított újfajta módszert alkalmaztunk, amit pár hónappal korábban, 50 alany bevonásával teszteltünk az Akasztói Horgászpark közelében.

A kérdőívezés során egy rövid, kutatásunkkal és az ökoszisztéma szolgáltatásokkal kapcsolatos általános ismertetőt követően arra kértük a résztvevőket, hogy segítség nélkül próbáljanak megemlíteni olyan javakat és szolgáltatásokat, melyeket szerintük a Biharugrai tavak nyújtani képesek. Ezt követően feltártuk előttük a kulcsinformátorok által összeválogatott szolgáltatások listáját, majd arra kértük őket, hogy emeljék ki közülük azon egyéb szolgáltatásokat is, melyeket szerintük az adott tavak szintén nyújtani képesek a korábban felsoroltak mellett, de megemlítésükről megfeledkeztek. Az előbbi kérdésre adott válaszok eredményeként valamennyi szolgáltatáshoz rendelhettünk egy ún. „említési értéket (e\%)”, ami azt mutatja meg nekünk, hogy az egyes szolgáltatásokat a megkérdezettek hány százaléka volt képes magától megemlíteni. Ezzel az értékkel elsődlegesen 
a résztvevők előzetes, az általunk felsorolt és kifejtett szolgáltatásokkal (tehát a kérdésfeltevés által) nem befolyásolt tudásának feltárását céloztuk meg (Babbie 2002, Newing et al. 2011). Az ezt követő kérdésre adott válaszok alapján mindezt kiegészíthettük egy-egy ún. „kiemelési értékkel (k\%)” is, amely a szolgáltatások listáról való kiemelésének gyakoriságát reprezentálja.

A kérdőívekben nem kérdeztünk rá az egyes szolgáltatások említésének vagy kiemelésének okára, ugyanis a tesztelések során azt tapasztaltuk, hogy ez a legtöbb alany számára megterhelö feladat volt, aminek gyakran hangot is adtak. Helyette inkább a megkérdezettek és a tavak közti korabeli és jelenlegi személyes kapcsolatokról érdeklődtünk. Célunk ezzel az volt, hogy feltárjuk milyen módon, milyen főbb tevékenységek során jutottak és jutnak alanyaink a rendelkezésükre álló információkhoz.

A szolgáltatásokat, azok e\% és $\mathrm{k} \%$ értékeinek együttes figyelembe vétele alapján négy népszerüségi csoportba $(\mathrm{A}, \mathrm{B}, \mathrm{C}, \mathrm{D})$ soroltuk, melyeken belül a fontossági sorrendet alapvetően az említési gyakoriság alapján határoztuk meg (utóbbiban a kiemelések gyakorisága leginkább azonos e\% értékek esetében játszott szerepet): az „A” csoportba a legfontosabb és a köztudatban leginkább elterjedt szolgáltatások tartoznak, melyek népszerüsítésére nincs vagy alig van szükség (jellemzöjük: e\% > k\%, 50\%). A „B” csoportba már a közismert, ám bizonyos mértékü népszerüsítést igénylő szolgáltatások kerültek (jellemzőjük: $\mathrm{e} \%>\mathrm{k} \%$; $50 \%>\mathrm{e} \%>10 \%$ ). Az előzőekkel ellentétben a „C” kategória már a köztudatból elhalványult szolgáltatásokat hordozza, melyek moderált mértékü népszerüsítést igényelnek (jellemzőjük: $\mathrm{k} \%>\mathrm{e} \%$; $\mathrm{k} \%>10 \%$ ). Mindezeken túl a „D” kategória tartalmazza azokat a köztudatból kiesett szolgáltatásokat, amely népszerüsítését csupán jelentős energia ráfordítás mellett lehetne végrehajtani (jellemzőjük: $\mathrm{e} \%, \mathrm{k} \%<10 \%$ ).

A kérdőívek kitöltéséhez az ún. „kvóta alapú mintavétel (quota sampling)” módszerének (Babbie 2002, Newing et al. 2011) egy különleges formáját alkalmaztuk: az általunk kijelölt, eltérő tulajdonságokkal bíró három környező településen (Biharugra, Zsadány, Komádi) 40-40 (összesen 120) személyt kértünk fel a kérdőív kitöltésére, majd megfigyeltük, hogy közülük hányan voltak azok, akik témánkat megismerve elvállalták és végrehajtották a feladatot. Kutatásunk során bárkit megkértünk a kérdőív kitöltésére, aki alapkritériumainknak (18. életévét betöltött helyi lakos) megfelelt. Az általunk használt mintavételi technika felhasználásával a Biharugrai-tavak szolgáltatásainak fontossági sorrendje mellett szerettük volna feltárni azt a településtípust is, ahol a legkönnyebben lehet megfelelő számú kérdőívet készíteni. A módszerválasztásunk legfőbb okát Tóth és mtsai. 2017-ben kiadott tanulmánya (Tóth et al. 2017) adta, ugyanis kutatásukban Tóth és mtsai. a Biharugrai-halastavak szolgáltatásainak szocio-kulturális értékelését 
követően nem tudtak szignifikáns különbséget tenni az általuk vizsgált 5 település (Biharugra, Zsadány, Körösnagyharsány, Geszt és Mezőgyán) lakosságának egyes szolgáltatásokra irányuló igényei között. Ez a megállapítás kérdésessé teszi valamennyi település együttes, viszonylag sok időt és ráfordítást igénylő vizsgálatának indokoltságát.

Minden kérdőívet interaktív módon, a lekérdező személyes jelenlétében töltettünk ki, hogy ezzel biztosítsuk a segítségnyújtás lehetőségét az alanyok számára (Newing et al. 2011). A lekérdezést minden esetben ugyanaz a személy végezte.

Azon személyektől, akik valamilyen oknál fogva visszautasították a kérdőív kitöltését, minden esetben megkérdeztük, hogy szerintük nagy általánosságban milyen javakat nyújthatnak a Biharugrai-halastavak. Eredményeiket szerettük volna összehasonlítani a kitöltött kérdőívekből származó rangsorral annak kiderítésére, hogy az tényleg a lakosság föbb véleményét tükrözi-e vagy sem.

\section{A kiválasztott települések leirása}

A kiválasztott települések közül Biharugra egy 896 fövel (KSH 2017) rendelkező község, csupán pár száz méterre ÉNY-ra a halastórendszer Ugrai egységtől. A település történelme szorosan összefonódik a tavak történetével: az Ugrai részen végzett haltermelés és egyéb feladatok (pl. nádaratás) sokáig a helybéliek egyik legmeghatározóbb megélhetési forrását biztosították. A jelenleg múködő halgazdaságok (Biharugrai Halgazdaság Kft., Agropoint Kft.) állandó dolgozóinak jelentős része még ma is biharugrai lakos (kulcsinformátor7 szóbeli közlés).

Zsadány község lakossága 1729 föt (KSH 2017) számlál. Maga a település a Begécsi egységtől néhány km-re, NY-ra helyezkedik el, így története elsősorban ehhez az egységhez kapcsolódik. Ez a kapcsolat azonban már korántsem olyan erőteljes, mint Biharugra és az Ugrai-tóegység között. Ezt támasztja alá az a tény is, hogy a Zsadányiak aránya a halgazdaságokban dolgozók között jelenleg elenyésző (kulcsinformátor7 szóbeli közlés).

A három település közül Komádi helyezkedik el legtávolabb (kb. $10 \mathrm{~km})$ a Biharugrai halastórendszertől. Az 5228 főt (KSH 2017) számláló várost emiatt csupán kevés korabeli és jelenkori kapcsolat füzi a tavakhoz (hiszen innen a legnehezebb eljutni hozzájuk).

\section{Demográfiai tényezök vizsgálata}

A kérdőívek készítése során a résztvevők különböző demográfiai tényezőire is rákérdeztünk annak kiderítése érdekében, hogy az egyes tényezökön belül vizsgált csoportok (pl. nők és férfiak) közül melyek azok, amelyek a legnagyobb befolyást gyakorolták a kérdőívekből származó eredményeinkre (Kelemen et al. 2015). 
A vizsgált demográfiai tényezők (és azok csoportjai): nem (nő/férfi), életkor (<20 / 20-39 / 40-59 / 60-79 / 80<), foglalkozás (közmunkás, szakmunkás, vállalkozó, nyugdíjas) a tavakhoz való látogatás gyakorisága (kevesebb, mint évi 1-szer / évente min. 1-szer / havonta / hetente / naponta). Elemzésünk során elsősorban azt vizsgáltuk, hogy méretükben mely csoportok emelkedtek ki szignifikánsan a többi közül és gyakoroltak ezzel dominanciát az adott demográfiai tényezőkön belül. Ez alól egyedül a nem volt kivétel, ahol is törekedtünk a nők és a férfiak hasonló arányú bevonására, annak a null-hipotézisnek a tesztelésére, miszerint: a két csoport hasonló gyakorisággal említ meg és emel ki szolgáltatásokat. A kapott eredményeket egy korábbi, szintén hazai kutatás nemekre vonatkozó megállapításaival (Kelemen et al. 2015) szerettük volna összehasonlítani. Amennyiben a nemen kívül valamelyik másik demográfiai tényezőn belül is egyszerre több csoport emelkedett ki hasonló arányban, akkor azok a szolgáltatások említésére és kiemelésére gyakorolt hatását szintén összehasonlítottuk. A csoportok összehasonlítását, azok különböző méretei és a normáltól gyakran eltérő eloszlásai miatt minden esetben Kruskal-Wallis teszt segítségével hajtottuk végre 95\%-os megbízhatósági szint mellett. Előzetesen, a normalitás teszteléséhez Shapiro-Wilk tesztet, a varianciák azonosságának megállapításához pedig Levene-tesztet alkalmaztunk. A statisztikai vizsgálatokat Past program segítségével végeztük.

\section{Eredmények}

\section{Szolgáltatásgyüjtés}

A tíz kulcsinformátorral végzett strukturált interjú során az alábbi 14 szolgáltatás került kiemelésre a Biharugrai halastavak vonatkozásában (zárójelben az egyes szolgáltatások kategóriája): haltermelés (ellátó), nádtermelés (ellátó), kikapcsolódási lehetóségek (kulturális), esztétikai élmény (kulturális), inspirációs forrás (kulturális), oktatás (kulturális), kutatásra való lehetőség (kulturális), természetközeli élőhelyek (élőhelyi), faji sokszínűség (élőhelyi), tisztább levegő (szabályzó), lokális klímaszabályozás (szabályzó), vízminőség szabályozás (szabályzó), vízraktározás (szabályzó) és talajvízutánpótlás (szabályzó).

A feltárt szolgáltatások között fennálló összefüggésekkel kapcsolatban az interjúalanyok jelentős része a haltermelés folyamatát emelte ki, mint központi, minden más szolgáltatásra hatást gyakorló tényezőt (, ...a halgazdálkodásnak, az ahhoz szükséges víznek köszönhetöen marad meg itt minden, ez mindenre hatással van..." (kulcsinformátor6)). Nagy jelentőséget tulajdonítottak a gazdálkodás fokának is: az intenzívebb módon kezelt (elsősorban a Biharugrai Halgazdaság Kft. alá tartozó) tavak esetében a haltermelést egyrészt a tisztább levegővel és a 
lokális klíma szabályozásával hozták egyenes arányú kapcsolatba: „,...nincs az, hogy a különbözö kotú-szervezetek felszaporodjanak, elgázosodjanak. Azok a növényi rothadó anyagok betermelödnek, elrohadnak... A legjobb levegö a termelö tavakon van, mert nincsenek rothadó növények és a szél is kavarja a levegöt" (kulcsinformátor5). Másrészt kiemelték, hogy ezek a típusú tavak viszonylag nagy mennyiségű víz minőségének szabályozását, javítását képesek végrehajtani: „,...jön befelé egy meddö viz, ami aztán megtisztul” (kulcsinformátor5).

A kevésbé intenzív módon kezelt illetve a kezelés alól kivont tavak a megkérdezettek szerint nagy szerepet játszanak a faji diverzitás, a nádtermelés és a legtöbb kulturális szolgáltatás (esztétika, rekreáció, inspirációs forrás, oktatás) biztosítása terén a természetközeli élőhelyek fenntartásán keresztül: „,Mindenki szeretné megelözni, hogy az élövilág negativ irányba változzon, mert az mind lelkiségében, mind az ökoszisztéma normális müködésében, mind pedig a látvány és a turisztika szempontjából sem mindegy...itt minden napra jut valami csoda" (kulcsinformátor2).

Mindezek mellett többen kiemelték, hogy bár maguk a tavak kevésbé vesznek részt a talajvíz utánpótlásában agyagos talajuk miatt, de az őket ellátó táplálócsatornák tapasztalható módon hozzájárulnak a környezetükben lévő mezőgazdasági területek fenntartásához a belölük elszivárgó víz segítségével: „,..a víz a csatornáknál elfolyik, szabadon...ezek a vízcsorgások mind segitséget jelentenek a mezögazdaság számára" (kulcsinformátor5).

A szolgáltatások fontossági sorrendje és csoportositása

A Biharugrai-halastavak környékén élö 120 személyböl összesen 43-an vállalkoztak a kérdőív kitöltésére, akik közül 27 fő (62,8\%) Biharugráról, 9 fö (20,9\%) Zsadányból, 7 fő (16,3\%) pedig Komádiból származott.

A kérdőívek adatai alapján a helybéliek számára a haltermelés és a rekreációs lehetőségek bizonyultak a két legfontosabb szolgáltatásnak. Utóbbiakat a válaszadók döntő többsége magától, tehát még a lista bemutatása előtt, megemlítette, ami miatt mindkettőt az „A" csoportba soroltuk. A „B” csoportot egyedül a faji sokszínúség alkotja. Minden más szolgáltatás a népszerúsítésre szoruló „C” csoportot gazdagítja, melyek közül a legmagasabb említési értékkel az esztétikai élmény rendelkezett. Olyan szolgáltatást, amely a helyiek számára teljesen ismeretlen lett volna („D” csoport) nem találtunk. A feltárt szolgáltatások listáját, azok fontossági sorrendjével és értékeivel együtt az 1. táblázatban mutatjuk be részletesen.

Azok a személyek, akik ugyan nem töltöttek ki kérdöívet, viszont hajlandóak voltak válaszolni arra a kérdésünkre, hogy szerintük a Biharugrai-halastavak milyen főbb szolgáltatásokat nyújthatnak (77fö), összesen 36 alkalommal beszéltek 
1. táblázat: A Biharugrai-halastavak szolgáltatásai és azok fontossági sorrendje (e\%: említések százalékos aránya, $\mathrm{k} \%$ : kiemelések százalékos aránya)

\begin{tabular}{clccc}
\hline Sorrend & \multicolumn{1}{c}{ Szolgáltatás } & $\mathrm{e} \%$ & $\mathrm{k} \%$ & Csoport \\
\hline 1. & Haltermelés & 69.0 & 23.8 & $\mathrm{~A}$ \\
2. & Kikapcsolódási lehetőség & 57.1 & 21.4 & $\mathrm{~A}$ \\
3. & Magas fajszám & 45.2 & 42.9 & $\mathrm{~B}$ \\
4. & Szép környezet, vonzó táj & 40.5 & 54.8 & $\mathrm{C}$ \\
5. & Természetes élőhelyek & 14.3 & 69.0 & $\mathrm{C}$ \\
6. & Oktatás & 11.9 & 69.0 & $\mathrm{C}$ \\
7. & A városhoz képest tisztább levegő & 9.5 & 88.1 & $\mathrm{C}$ \\
8. & Inspirációs forrás & 4.8 & 50.0 & $\mathrm{C}$ \\
9. & Vízbe került szennyeződések csökkentése & 2.4 & 78.6 & $\mathrm{C}$ \\
10. & Nádtermelés & 2.4 & 69.0 & $\mathrm{C}$ \\
11. & A városhoz képest egyenletesebb hö- és csapadékeloszlás & 2.4 & 64.3 & $\mathrm{C}$ \\
12. & Kutatásra való lehetőség & 2.4 & 50.0 & $\mathrm{C}$ \\
13. & Talajvízutánpótlás & 0.0 & 61.9 & $\mathrm{C}$ \\
14. & Vízvisszatartás és raktározás & 0.0 & 50.0 & $\mathrm{C}$ \\
\hline
\end{tabular}

nekünk a haltermelésröl, mint nyújtott szolgáltatásról, 32-szer a kikapcsolódási lehetőségekről (A), 7-szer a faji sokféleségről (B), 5-ször az esztétikai élményröl (C) illetve 1-1-szer hivatkoztak még a tiszta levegőre (C), a kutatásra való lehetőségre (C), a vízminőség szabályozásra (C) és az oktatásra (C) is. Ez az említési sorrend hasonló mintázatot mutat a kérdőívek kiértékeléséből származó rangsorral, amely bizonyos mértékben alátámasztja kapott eredményeinket. Ennek szemléltetésére valamennyi előbb felsorolt szolgáltatás mellett feltüntettük, hogy azok mely népszerüségi csoportba kerültek besorolásra a kérdőívek kiértékelése alapján.

\section{Demográfiai tényezök}

Nem: vizsgálataink során a nemek hasonló arányban képviseltették magukat 20 nő (46,5\%) és 23 férfi (53,5\%) részvételével (1. ábra). A két csoport között nem találtunk szignifikáns eltérést 95\%-os megbízhatósági szint mellett sem az ismert (Shapiro-Wilk-teszt: $\mathrm{p}_{\mathrm{N}}=0,3706, \mathrm{p}_{\mathrm{F}}=0,0454$; Levene-teszt: $\mathrm{p}=0,1095$; KruskalWallis teszt: $\mathrm{p}=0,8914$ ), sem a kiemelt szolgáltatások (Shapiro-Wilk-teszt: $\mathrm{p}_{\mathrm{N}}=0,0099, \mathrm{p}_{\mathrm{F}}=0,0007$; Levene-teszt: $\mathrm{p}=0,9534$; Kruskal-Wallis teszt: $\mathrm{p}=0,2599$ ) számában, amiből arra következtettünk, hogy a nemnek valószínüleg nincs számottevő hatása az emberek szolgáltatás ismeretére. 
Nemek megoszlása

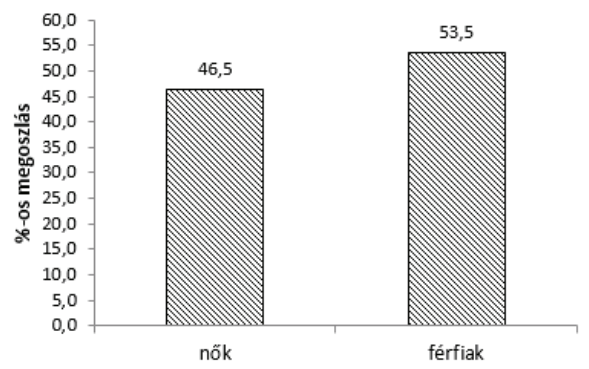

Kijárás gyakorisága

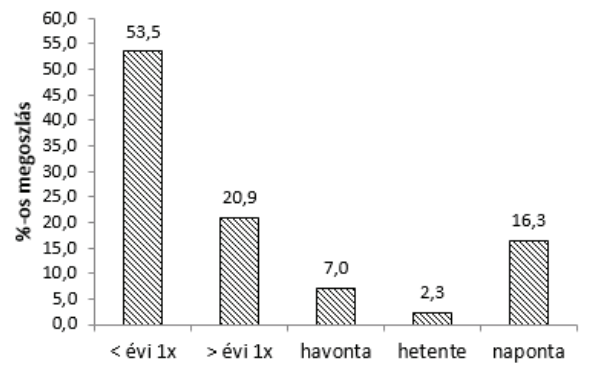

Kormegoszlás

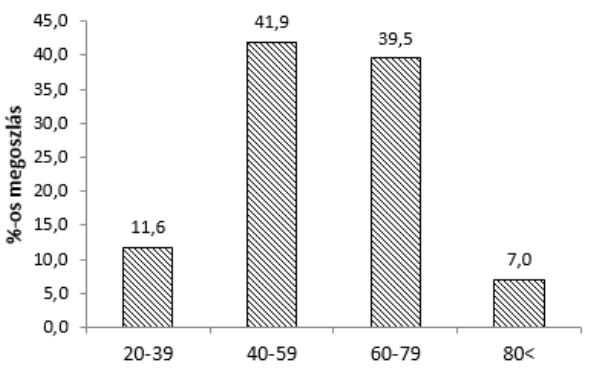

Foglalkozás

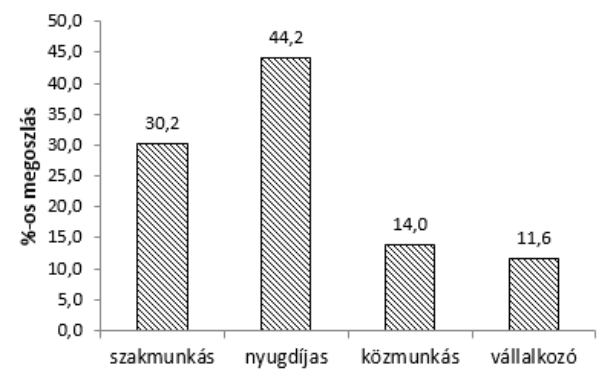

1. ábra: A szocio-kulturális értékelésben részt vevő személyek demográfiai adatai.

Foglalkozás: túlsúlyban voltak a nyugdíjban részesülő személyek (19 fö, 44,2\%) illetve a szakmunkából élők (13 fö, 30,2\%), ám mellettük, kis számban ugyan, de képviseltették magukat közmunkások (6 fö, 14\%) és vállalkozók (5 fö, $11,6 \%$ ) is (1. ábra). Mivel a szakmunkások és a nyugdíjasok részvételének aránya egyaránt magas és egymáshoz viszonylag hasonló volt, ezért a két csoport szolgáltatásokkal kapcsolatos ismereteit összehasonlítottuk egymással. Eredményeink szerint a két csoport között 95\%-os megbízhatósági szint mellett ugyan nem mutatkozott szignifikáns különbség a szolgáltatások ismeretében (Shapiro-Wilkteszt: $\mathrm{p}_{\text {szak }}=0,1361, \mathrm{p}_{\text {nyug }}=0,0974$; Levene-teszt: $\mathrm{p}=0,1463$; Kruskal-Wallis teszt: $\mathrm{p}=0,0609$ ), viszont azok kiemelésében már igen (Shapiro-Wilk-teszt: $\mathrm{p}_{\text {szak }}=0,2398$, $\mathrm{p}_{\text {nyug }}=0,1480$; Levene-test: $\mathrm{p}=0,0320$; Kruskal-Wallis teszt: $\mathrm{p}=0,0058$ ), ugyanis a szakmunkások átlagosan több szolgáltatást tudtak kiemelni, mint a nyugdíjas korú lakosok.

Életkor: 5 válaszadó $(11,6 \%)$ tartozott a 20-39 év közötti korosztályba, 18an (41,9\%) a 40-59 év közöttiekhez, 17-en (39,5\%) a 60-79 éves csoporthoz és 3-an (7\%) a legidősebb, 80 év feletti korosztályba (1. ábra). 20 év alatti személyekkel (akik már betöltötték 18. életévüket) nem tudtunk kérdőívet készíteni a rendelkezésünkre álló idő alatt. Mivel a 40-59 év és a 60-79 év közötti korosztá- 
lyok részvételének aránya egyaránt magas és egymáshoz viszonylag hasonló volt, ezért a két csoport szolgáltatásokkal kapcsolatos ismereteit összehasonlítottuk egymással. A statisztikai vizsgálatok alapján a két csoport között sem a szolgáltatások ismerete (Shapiro-Wilk-teszt: $\mathrm{p}_{40-59}=0,0799, \mathrm{p}_{60-79}=0,2841$; Levene-teszt: $\mathrm{p}=0,2295$; Kruskal-Wallis teszt: $\mathrm{p}=0,0635$ ), sem pedig azok kiemelése (ShapiroWilk-teszt: $\mathrm{p}_{40-59}=0,0003, \mathrm{p}_{60-79}=0,1708$; Levene-teszt: $\mathrm{p}=0,2605$; Kruskal-Wallis teszt: $\mathrm{p}=0,2209)$ terén nincs szignifikáns különbség 95\%-os megbízhatósági szint mellett. A további pontosításhoz érdemes kiemelni, hogy a 70 év felettiek esetében a szolgáltatások ismeretének és kiemelésének gyakorisága már észrevehetően alulmaradt a többi korosztályhoz képest, ami bizonytalanná teszi megkérdezésük jelentőségét.

A tavak látogatásának gyakorisága: a megkérdezettek több mint fele, pontosabban 23 fö (53,5\%), évi egy alkalomnál kevesebbszer látogat ki a tavak területére, 9 fö $(20,9 \%)$ évente legalább egyszer, 3 fö (7\%) havonta, 1 fö (2,3\%) hetente, 7 fö (16,3\%) pedig napi rendszerességgel kerül kapcsolatba a tavakkal (1. ábra). Az évente 1-nél kevesebb alkalommal ellátogató személyek magas arányát elsősorban az idősebb korosztályok dominanciája magyarázza, ugyanis a megkérdezett személyek jelentős része, pontosabban 43-ból 19 fő (44,2\%) már átlépte a nyugdíjkorhatárt. Utóbbi személyek közül 16 tartoznak az 1 évnél ritkábban látogatók csoportjába. Az idősebb személyek gyakran maguk hívták fel figyelmünket arra, hogy korukból adódóan már nem járnak rendszeresen a tavakhoz.

Arra a kérdésre, hogy milyen személyes kapcsolatok kötik őket a tavakhoz, a legtöbb helybéli azt a választ adta, hogy már gyermekkora óta ismeri azokat. A megkérdezettek 34,9\%-a (15 fö) fiatal korában kikapcsolódni (horgászni, túrázni, „nézelődni”), 18,6\%-uk pedig dolgozni (főleg nyári munkára) járt oda. Az alanyok 7\%-t (3 fö) továbbá valamilyen családi kapcsolat kötötte a tavakhoz. Jelenleg az emberek többsége munkavégzés céljából jár ki (18,6\%, 8 fö), ám viszonylag nagy az aránya azoknak is, akik csupán kikapcsolódni szeretnének (14\%, 6 fó). Utóbbiban a kilátók nagy szerepet töltenek be, melyeket a helyiek olykor családosan is látogatnak (4,7\%, 2 fó). A válaszadók többi része vagy azért keresi fel a tavakat, hogy annak látványában gyönyörködjön $(9,3 \%, 4$ fö) vagy pedig azért, hogy halat vásároljon a termelöktől (4,7\%, 2 fö).

\section{Értékelés}

Kutatásunk során egy hazai viszonylatban új, általunk kialakított módszert alkalmaztunk a Biharugrai halastórendszer szolgáltatásainak igény alapú szociokulturális értékelésének elvégzéséhez, melyben az általánosan elterjedt listás le- 
kérdezés és a szolgáltatások fontossági sorrendjének megadása mellett nagyobb hangsúlyt fektettünk az emberek előzetes, a szolgáltatások általunk végzett felsorolásával és kifejtésével nem befolyásolt tudására, hogy azzal eredményeinket a lehető legközelebb állítsuk a valósághoz.

Az egyes szolgáltatások köztudatban elfoglalt helyének jobb szemléltetésére, illetve a népszerüsítésükre irányuló esetleges jövőbeli intézkedések egységesítése és megkönnyítése érdekében, népszerüségi csoportokba soroltuk valamennyi szolgáltatást, melyre a szakirodalomban nem találtunk korábbi esetet. Csoportosításunk rámutat arra a tényre, hogy a Biharugrai-halastavak szolgáltatásainak közel 80\%-a népszerüsítésre szorul.

A szolgáltatások előzetes megállapítására a Tóth és mtsai. által alkalmazott dokumentum elemzés módszere mellett (Tóth et al. 2017) kulcsinformátorokkal végzett strukturált interjúkészítést is alkalmaztunk egy korábbról származó általános lista (Kerepeczki et al. 2011) segítségével annak reményében, hogy a reprezentatív módon összeválogatott szakértők tudásával pontosabb képet alkothatunk a fennálló viszonyokról és javakról. Ennek köszönhetően a minket megelőző kutatás eredményeit nemcsak két újabb szolgáltatással egészítettük ki (faji diverzitás, tisztább levegö), de közben azt is megtudtuk, hogy a kulcsinformátorok a haltermelést és a természetes élőhelyek meglétét tekintik a két központi szolgáltatásnak, melyek jelenlétükkel szerintük minden másra hatást gyakorolnak. Megőrzésük kérdését ebből kiindulva elsődleges fontossággal lenne érdemes kezelni.

Az interjúk alapján kialakított és a három közeli, egymástól eltérő tulajdonságokkal rendelkező település (Biharugra, Zsadány, Komádi) lakossága körében bemutatott kérdőívek sikeres kitöltésének százalékos megoszlásai jól szemléltetik, hogy egyenlő számban felkért személyek mellett a többi település együttes eredményeinél majdnem kétszer több kérdőívet, tudtunk kitöltetni azon a településen (Biharugrán), amely ugyan a legkisebb lélekszámmal rendelkezett, viszont az előzetes dokumentumelemzések és interjúk alapján a leginkább kötődött a tavakhoz (történelmileg és jelen körülmények szerint is). Utóbbi a Biharugrai, és más, hozzá hasonló hazai halastórendszerek esetében megkérdőjelezi valamennyi település teljes körü, nagy idő és forrásigényü vizsgálatának (Tóth et al. 2017) szükségességét.

Fontos kiemelni továbbá, hogy a szakirodalom ajánlásával ellentétben (SantosMartin et al. 2017), mi nem alkalmaztunk 1-5-ig terjedő skálát illetve fényképes tablót a szolgáltatások fontossági sorrendjének meghatározásánál. Ennek oka, hogy bár mindkét módszer emeli a kapott információ mennyiségét, kivitelezésük a gyakorlatban nehézségekbe ütközik (Tóth et al. 2017) ugyanis a kérdések skálán történő megválaszolása viszonylag nagy (olykor túl nagy) jártasságot vár el a helyiek részéről mind a tavak, mind pedig az ökoszisztéma szolgáltatások 
terén. Ezt támasztja alá, hogy egyik kulcsinformátorunk (tehát a halastavak egyik szakértője), aki alanyként részt vett a minket megelőző kutatásban (Tóth et al. 2017) kiemelte, hogy többször nehézséget okozott számára a skálázott értékek pontos megadása. Hogy megkönnyítsük a megkérdezett személyek dolgát, és ezzel növeljük válaszaik megbízhatóságát, mi inkább az egyszerübb és közérthetőbb ismeri/nem ismeri típusú kérdésekhez ragaszkodtunk.

A fotótablók használatával kapcsolatban Kelemen és mtsai. (Kelemen et al. 2015), már korábban kiemelték, hogy még a nagy odafigyelés mellett, szakértői csoportok bevonásával megszerkesztett képek is idézhetnek elő félreértéseket, így ezt a módszert is mellőztük.

A kérdőívek eredményei alapján az azt kitöltő személyeket elsősorban a kikapcsolódás és a munka lehetősége köti a tavakhoz, döntő részüknek pedig már gyermekkora óta van valamilyen kapcsolata a területtel. Utóbbiak közül a 40-69 év közöttiek voltak a legnagyobb arányban. Jelentős részük ugyan nyugdíjas korú, ami jól szemlélteti a terület lakosságának elöregedését, viszont azt tapasztaltuk, hogy a legtöbb szolgáltatást mégsem ők, hanem a náluk valamivel alacsonyabb számban megjelenő, a tavak környékét gyakrabban látogató szakmunkások tudták kiemelni számunkra. Ez a tény a velük készített strukturált interjúk számának megnövelését teszi megfontolandóvá. Ennek ellenére nem szabad elfelejteni, hogy a szolgáltatások iránti igények pontos feltárása a lehető legtöbb társadalmi csoport bevonását igényli.

Ezen a terén érdemes kiemelni, hogy Kelemen és munkatársainak (Kelemen et al. 2015) eredményeivel ellentétben nem kaptunk szignifikáns eltérést a nemek esetében. Valószínüleg nagy szerepet játszik ebben az a tény, hogy az alacsony mintaelemszám miatt a különböző demográfiai tényezők hatását csupán a szolgáltatások összességében vizsgáltuk. Több kérdőív kitöltése mellett azonban a kutatást tovább lehet fejleszteni a szolgáltatások külön-külön történő elemzésével, hasonlóan az előbb említett kutatáshoz. Az utóbbiak fényében szeretnénk kiemelni, hogy a sikeresen kitöltött kérdöívek száma miatt a kapott eredményeket érdemes alapos körültekintés mellett kezelni.

A közeljövőben szeretnénk tovább folytatni a Biharugrai halastórendszer ökoszisztéma szolgáltatásainak vizsgálatát annak érdekében, hogy eddigi szociokulturális eredményeinket komplex gazdasági és ökológiai értékeléssel egészíthessük ki és ezzel olyan, hatékony fejlesztési tervek megfogalmazását segítsük elő, melyekben a szolgáltatások formái, illetve azok mennyisége, értéke és fejlesztési lehetőségei mellett a helyi tudás is megmutatkozik.

Köszönetnyilvánítás - Köszönet illeti a Körös-Maros Nemzeti Park Igazgatóság, a Magyar Madártani Egyesület, az Agropoint Kft., a Biharugrai Halgazdaság Kft., a Bihar Közalapítvány munkatársait és minden kulcsinformátort akik segítségünkre voltak az interjúk 
készítése során, továbbá minden egyes válaszadót, akik részt vettek kérdőívünk kitöltésében vagy valamilyen formában segítették munkánkat. Külön köszönettel tartozunk a Bihari Madárvártának a szívélyes vendéglátásért. Jelen munkánk a Kutatói Utánpótlást Elösegítő Program és az Európai Unió Aquaspace projektjének (No.: 633476) támogatásával valósulhatott meg.

\section{Irodalomjegyzék}

Andersson, E., Nykvist, B., Malinga, R., Jaramillo, F. \& Lindborg, R. (2015): A social-ecological analysis of ecosystem services in two different farming systems. - Ambio. 44: 102-112. doi: https://doi.org/10.1007/s13280-014-0603-y

Babbie, E. R. (ed.) (2002): The Basics of Social Research. - Wadsworth Thomson Learning, CA., Belmont, $542 \mathrm{p}$.

Balmford, A., Bruner, A., Cooper, P., Costanza, R., Farber, S., Green, R.E., Jenkins, M., Jefferiss, P., Jessamy, V., Madden, J., et al. (2002): Economic reasons for conserving wild nature. - Science 297: 950-995. doi: https://doi.org/10.1126/science.1073947

Bezdán, M. (2011): A szabályozott Tisza vizjárása tulajdonságai a Tiszafüred alatti folyószakaszokon. - Doktori (PhD) értekezés. SZTE TTIK Természeti Földrajzi és Geoinformatikai Tanszék, Földtudományok Doktori Iskola, Szeged, $120 \mathrm{p}$.

Bíró, L. (szerk.) (2009): Körös-Maros Nemzeti Park - Kis-Sárrét. - JAVIPA Nyomdaipari Kft., Békéscsaba, $16 \mathrm{p}$.

Blayac, T., Mathé, S., Rey-Valette, H. \& Fontaine, P. (2014): Perceptions of the services provided by pond fish farming in Lorraine (France). - Ecol. Econ. 108: 115-123. doi: https://doi. org/10.1016/j.ecolecon.2014.10.007

Csatári, B., Gaborjákné Dr. Vydareny, K., Kiss, A. \& Kovács, A. (szerk.) (2001): A Tisza-vidék problémái és fejlesztési lehetőségei. A Földmüvelésügyi és Vidékfejlesztési Minisztérium Vidékfejlesztési Föosztálya megbizásából készült Tisza-vidék kutatás-fejlesztési program összefoglalója. - MTA RKK Alföldi Tudományos Intézete, Kecskemét, 103 p.

Chan, K., Guerry, A., Balvanera, P., Klain, S., Satterfield, T., Basurto, X., Bostrom, A., Chuenpagdee, R., Gould, R., Halpern, B., Hannahs, N., Levine, J., Norton, B., Ruckelshaus, M., Russell, R., Tam, J. \& Woodside, U. (2012): Where are 'Cultural' and 'Social' in Ecosystem Services? A Framework for Constructive Engagement. - BioSci. 62: 744-756. doi: https://doi.org/10.1525/ bio.2012.62.8.7

Daily, G., Postel, S., Bawa, K. \& Kaufman, L. (eds.) (1997): Nature’s Services: Societal Dependence On Natural Ecosystems. - Bibliovault OAI Repository, The University of Chicago Press, Chicago, $392 \mathrm{p}$.

Deák, A. A. (szerk.) (1996): A háromszögeléstől a Tisza-szabályozásig. - Vízügyi Múzeum, Levéltár és Könyvgyüjtemény, Budapest, 128 p.

de Groot, R. (2006): Function-analysis and valuation as a tool to assess land use conflicts in planning for sustainable, multi-functional landscapes. - Landsc. Urban Plan. 75: 175-186. doi: https://doi. org/10.1016/j.landurbplan.2005.02.016

Duray, B. (2009): Tájdinamikai vizsgálatok - A tájhasználat-változás és regenerációs potenciál összefüggéseinek modellezése. - Doktori (PhD) értekezés, Szegedi Tudományegyetem, Földtudományi Doktori iskola, Szeged, 136 p. 
Horoszné Gulyás, M. (2010): Birtoktervezési és rendezési ismeretek 8., BTRI8 modul, Vásárhelyi Terv birtokrendezési összefüggései. - Nyugat-magyarországi Egyetem, Geoinformatikai Kar, Székesfehérvár, $17 \mathrm{p}$.

Nagy, Sz. \& Könczey, R. (szerk.) (1995): Természetvédelem a halastavakon. - Ikon Kiadó, Budapest, $58 \mathrm{p}$.

Juhász, P., Kiss, B., Olajos, P. \& Grigorszky, I. (2000): Vízi makroszkópikus gerinctelenek faunisztikai vizsgálata a Körös-Maros Nemzeti Park müködési területén. - Crisicum 3: 141-156.

Kelemen, E. (2013): Az ökoszisztéma szolgáltatások közösségi részvételen alapuló, ökológiai közgazdaságtani értékelése. - Doktori (PhD) értekezés, SZIE, Környezettudományi Doktori Iskola, $18 \mathrm{p}$.

Kelemen, E., Bela, Gy. \& Pataki, Gy. (szerk.) (2010): Módszertani útmutató a természet adta javak és szolgáltatások nem pénzbeli értékeléséhez. ESSRG Füzetek 2/2010. - SZIE Környezet-, és Tájgazdálkodási Intézet, Környezetgazdaságtani Tanszék, Gödöllö, 24 p.

Kelemen, E., Lazányi, O., Arany, I., Aszalós, R., Bela, Gy., Czúcz, B., Kalóczkai, Á., Kertész, M., Megyesi, B. \& Pataki, Gy. (2015): Ökoszisztéma szolgáltatásokról a kiskunsági Homokhátság társadalmának szemszögéből. - Termvéd. Közlem. 21: 116-129.

Kelemen, E. \& Pataki, Gy. (2014): Az ökoszisztéma szolgáltatások értékelésének elméleti megalapozása. - In: Kelemen, E. \& Pataki, Gy. (szerk.): Ökoszisztéma szolgáltatások: A természetés társadalomtudományok metszéspontjában. - SZIE KTI - ESSRG, Gödöllö -Budapest, pp. $37-57$.

Kerepeczki, É., Gyalog, G., Halasi-Kovács, B., Gál, D. \& Pekár, F. (2011): Extenzív halastavak ökológiai értékei és funkciói. - Halászatfejl. 33: 47-54.

Kovács, E., Kelemen, E. \& Pataki, Gy. (2011): Ökoszisztéma szolgáltatások a tudományterületek és a szakpolitikák metszéspontjaiban. - Termvéd. Közlem. 17: 1-11.

KSH, Központi Statisztikai Hivatal (2017): Magyarország közigazgatási helynévkönyve, 2017. január 1. - Központi Statisztikai Hivatal, Budapest, 227 p.

Lehota, J. (szerk.) (2001): Marketingkutatás az agrárgazdaságban. - Mezőgazda Kiadó, Budapest, $233 \mathrm{p}$.

Margóczi, K. (szerk.) (1998): Természetvédelmi biológia. - JATE Press, Szeged, 108 p.

Martín-López, B., Gómez-Baggethun, E., García-Llorente, M. \& Monte, C. (2014): Trade-offs across value-domains in ecosystem services assessment. - Ecol. Ind. 37: 220-228. doi: https:// doi.org/10.1016/j.ecolind.2013.03.003

Mathé, S. \& Rey-Valette, H. (2015): Local knowledge of pond fish-farming ecosystem services: management implications of stakeholders' perceptions in three different contexts (Brazil, France and Indonesia). - Sustainability 7: 7644-7666. doi: https://doi.org/10.3390/su7067644

MEA, Millennium Ecosystem Assessment (2005): Ecosystem and Human Well-being: Synthesis. World Resource Institute, Washington DC., 137 p.

Newing, H., Eagle, C. M., Puri, R. K. \& Watson, C. W. (eds.) (2011): Conducting research in conservation. Social science methods and practice. - Routledge Taylor Francis Group, London and New York, $376 \mathrm{p}$.

Oláh, J., Pekár, F. \& Váradi, L. (szerk.) (2009): Extenziv halastavi gazdálkodás és ökoturisztikai fejlesztés, Biharugrai-halastavak esettanulmány. - MME, Biharugra-Budapest, $27 \mathrm{p}$.

Palomo, I., Martín-López, B., López-Santiago, C. \& Montes, C. (2011): Participatory scenario planning for protected areas management under the ecosystem services framework: the Doñana social-ecological system in southwestern Spain. -Ecol. Soc. 16: 23.

Penksza, K., Házi, J., Héjja, P., Nagy, A., Bajor, Z., Sutyinszki, Zs., Malatinszky, Á. \& Szentes, Sz. (2010): Cönológiai vizsgálatok Biharugra környéki mocsári területeken. - Crisicum 6: 95-116. 
Pretty, J. (2003): Social capital and the collective management of resources. - Science 302: 19121914. doi: https://doi.org/10.1126/science. 1090847

Rakonczai, J. (2001): A környezeti változások hatása az alföldi táj átalakulására. - A Magyar Földrajzi Konferencia 2001 CD kiadványa, 16 p.

Reilly, K., Adamowski, J. \& John, K. (2018): Participatory mapping of ecosystem services to understand stakeholders' perceptions of the future of the Mactaquac Dam, Canada. - Ecosyst. Serv. 30: 107-123. doi: https://doi.org/10.1016/j.ecoser.2018.01.002

Santos-Martin, F., Kelemen, E., Garcia Llorente, M., Jacobs, S., Oteros-Rozas, E., Barton, D., Palomo, I., Hevia, V. \& Martín-López, B. (2017). Socio-cultural valuation approaches. - In: Benjamin, B. \& Joachim, M. (eds.) (2017): Mapping Ecosystem Services, Chapter: 4.2. Pensoft Publishers, Sofia, pp. 104-114.

Somogyi, S. (szerk.) (2000): A XIX. századi folyószabályozások és ármentesitések földrajzi és ökológiai hatásai Magyarországon. - MTA FKI, Budapest, 302 p.

Stefanovits, P., Filep, Gy. \& Füleki, Gy. (szerk.) (1999): Talajtan. - Mezőgazda Kiadó, Budapest, $470 \mathrm{p}$.

TEEB, Pushpam, K. (ed.) (2010): The Economics of Ecosystems and Biodiversity: Ecological and Economic Foundations. - Earthscan, London and Washington, $410 \mathrm{p}$.

Tóth, F., Jancsovszka, P., Kerepeczki, É. \& Kelemen, E. (2017): A Biharugrai-halastavak ökoszisztéma-szolgáltatásainak szociokulturális értékelése. - Termvédelmi Közlem. 23: 224-241. doi: https://doi.org/10.20332/tvk-jnatconserv.2017.23.224

Tőgye, J. (2006): Természetvédelem mesterséges halastavakon - A Biharugrai-halastavak. - Szakmérnöki diplomadolgozat, Debreceni Egyetem, Mezőgazdaságtudományi Kar, Természetvédelmi Állattani és Vadgazdálkodási Tanszék, Debrecen, 87 p.

Turkelboom, F., Thoonen, M., Jacobs, S., García-Llorente, M., Martín-López, B. \& Berry, P. (2016): Ecosystem services trade-offs and synergies (draft). - In: Potschin, M. \& Jax, K. (eds.): OpenNESS Ecosystem Services Reference Book.

Ungvári, G., Molnár, Zs., Varga, Gy. \& Ellison, D. (szerk.) (2012): Ökoszisztéma-szolgáltatások nagyságrendi becslése vízgyüjtő szinten a vízkörforgást leíró vízháztartási jellemzők alapján. Mühelytanulmány (working paper). Regionális Energiagazdálkodási Kutatóközpont, Budapest, $31 \mathrm{p}$.

Vágás, I. (1996): Gondolatok Vásárhelyi Pál Tisza-szabályozási tervéből. - Hidr. Közl. 6: 336.

Völgyesi, I. (2005): Mennyit termelhetünk a felszín alatti vízkészletekből? - Hidr. Közl. 5: 20-24.

Völgyesi, I. (2009): Ökológiai vízigény, vagy megfelelö talajvízszintek. - Hidr. Közl. 5: 53-56.

West, P. (ed.) (2006): Conservation is our government now: The politics of ecology in Papua New Guinea. - Duke University Press, NC., Durham, 352 p.

Wu, Y., Jie, C., Bin, X., Changhui, P. \& Ying, G. (2008): Ecosystem service value assessment for constructed wetlands: A case study in Hangzhou, China. - Ecol. Econ. 68: 116-125. doi: https:// doi.org/10.1016/j.ecolecon.2008.02.008 


\title{
The Biharugra fishpond systems' ecosystem services from the locals' view - multiphasic sociocultural valuation
}

\author{
Péter Palásti and Éva Kerepeczki \\ National Agricultural Research and Innovation Centre, Institute of Fisheries, \\ H-5540 Szarvas, Anna-liget 8, Hungary \\ e-mail:palasti.peter@haki.naik.hu
}

By the sideffects of the great river regulations, the range of Hungary's natural wetlands' and the quantity and quality of their ecosystem services were decreased. Artificial habitats like the Biharugra fishpond system could partially take their role, what makes their long-term and sustainable usage an important question. Our goal is to support the sustainable use of the country's semi-natural fishponds with the collection and socio-cultural assessment of their services and to create new, better methods for service-ranking. During our study we have performed 10 structured interviews with local key-informants to reveal the list of the Biharugra fishponds' ecosystem services. After that we conducted a survey based socio-cultural assessment in three nearby settlements to put the services in order by the demands of local people, using a new valuation method. So far we have managed to collect 14 relevant services of the ponds, from which fishing, recreation and the diversity of species were the three most favorite services among the locals. With our other results, mostly about the effects of multiple demographic factors, choosing of the most relevant study areas (settlements) and the benefits of our new socio-cultural valuation method, we would like to supplement the findings of other previous studies in the field.

Keywords: ecosystem services, sociocultural valuation, Biharugra fishponds 